\title{
Indomethacin is Effective Against Neurogenic Hyperthermia Following Cranial Trauma or Brain Surgery
}

\author{
G. Benedek, P. Tóth-Daru, J. Janáky, A. Hortobágyi, F. Obál Jr. and K. Colner-Sasi
}

\begin{abstract}
The effectiveness of indomethacin treatment $(1 \mathrm{mg} / \mathrm{kg})$ as an antipyretic was tested in patients after cranial trauma or brain surgery involving the centromedial forebrain. Indomethacin was effective in reducing temperature in 10 of 11 cases which showed a dipyrone-resistant hyperthermia developing in the first 24 hours after brain damage, while no significant antipyretic effect was seen in hyperthermic cases developing more than 72 hours aiter cranial trauma or brain surgery. Biochemical tests estimating the effect of indomethacin, and pyrazolone derivatives on the arachidonic acid metabolism showed significant effects of indomethacin only in influencing cyclooxygenase activity and no effect of any drugs on lipoxy - genase actions. In view of these observations, the use of indomethacin is recommended as a treatment for neurogenic hyperthermia.
\end{abstract}

RÉSUMÉ: L'indométhacine est efficace dans le traitement de l'hyperthermie neurogène survenant à la suite d'un traumatisme crânien ou d'une chirurgie intra-crânienne L'efficacité de l'indométhacine ( $1 \mathrm{mg} / \mathrm{kg}$ ) comme traitement antipyrétique a été vérifiée chez des patients ayant subi un traumatisme crânien ou une chirurgie impliquant la région centromédiane du prosencéphale. L'indométhacine a été efficace chez 10 des 11 patients ayant présenté une hyperthermie résistante au dipyrone dans les premières 24 heures après avoir subi la lésion cérébrale, alors qu'on n'a observé aucun effet antipyrétique significatif chez les patients ayant développé une hyperthermie plus de 72 heures après avoir subi un traumatisme crânien ou une chirurgie du cerveau. Des épreuves biochimiques faites dans le but d'évaluer l'effet de l'indométhacine et de dérivés de la pyrazolone sur le métabolisme de l'acide arachidonique ont montré un effet significatif de l'indométhacine seulement sur l'activité de la cyclo-oxgénase et aucun effet médicamenteux sur l'activité de la lipoxygénase.

Suite à ces observations, nous recommandons l'utilisation de l'indométhacine dans le traitement de l'hyperthermie neurogène.

Can. J. Neurol. Sci. 1987: 14:145-148

Neurogenic hyperthermia is a general term used for increased body temperature due to lesions in the centromedial forebrain around the third ventricle. Such hyperthermia has been observed in association with cranial trauma, cerebral emboli, neurosurgical intervention, expansive intracranial tumors and thromboses of the cerebral venous sinuses (see review by Rudy).' Neurogenic hyperthermia is resistant to traditional antipyretic treatment. $^{2.3}$ Animal experiments suggest that neurogenic hyperthermia caused by damage to the anterior hypothalamus/ preoptic region can be prevented by indomethacin, a highly potent inhibitor of prostaglandin (PG) synthesis. ${ }^{4,5}$

Indomethacin is rarely used as an antipyretic except in fevers of neoplastic origin..$^{6,7} \mathrm{We}$ attempted to influence the hyperthermic states that were presumably of neurogenic origin with the administration of indomethacin. Since pyrazolone derivatives are widely used in our country, we performed a comparative study in which the effectiveness of indomethacin and the non-acidic pyrazolone dipyrone were tested in hyperthermias associated with brain damage. The effectiveness of indometha- cin and a series of pyrazolone derivates on arachidonic acid metabolism were also tested.

\section{SUBJECT AND METhODS}

Clinical studies A comparative study on the treatment of neurogenic hyperthermia was performed over the time period from January 1, 1982 and December 31, 1983. The study was conducted in conformity with the principles detailed in the Declaration of Helsinki and was approved by the Human Investigation Review Board of the University of Szeged. Informed consent was obtained from every participant or family members. All patients that developed fever after forebrain lesion, and whose fever proved to be resistant to intravenous dipyrone $(20 \mathrm{mg} / \mathrm{kg}$ ), were treated with indomethacin in rectal suppositories ( $1 \mathrm{mg} / \mathrm{kg}$ ). Dipyrone was assessed ineffective if it failed to decrease the body temperature to below $38.0^{\circ} \mathrm{C}$ within $30 \mathrm{~min}$ utes of administration. Body temperature was measured in the axillary cavity as a routine procedure at $\mathbf{3 0} \mathrm{min}$ intervals. The

From the Department of Physiology (Drs. Benedek and Obál); and Department of Neurosurgery (Drs. Tóth-Daru and Hortobágyi), University Medical School, Szeged and Drug Research Institute (Drs. Janáky and Colner-Sasi), Budapest. Hungary

Received June 17, 1986. Accepted in final form January 6, 1987

Reprint requests to: György Benedek, Department of Physiology, University Medical School, Szeged, H-6720, Dóm tér 10. Hungary 
patients were classified into two groups depending on the interval between brain trauma and the onset of fever. All patients in group 1 suffered brain damage or had brain surgery less than 48 hours before the development of fever. In this group no cause of fever other than central trauma was detected. In group 2 fever developed at least 72 hours after brain trauma or surgery. The fever in most of these cases was due to infections and was resistant to dipyrone treatment. Indomethacin was given $\mathbf{3 0}$ minutes after an ineffective dipyrone treatment.

Biochemical studies The two pathways of arachidonic acid metabolism were studied. Biochemical assessments were done according to the method of Grossman and Zokut. ${ }^{9}$

\section{1) The effect of drugs on the cyclooxygenase enzyme.}

PG synthetase enzyme was obtained from ram seminal vesicle gland. The substances were dissolved in a fluid containing gluthathion and were incubated with the enzyme and $\mathrm{H}^{3}$ arachidonic acid. Prostaglandin $\mathrm{E}_{2}\left(\mathrm{PGE}_{2}\right)$ was extracted by ethylether then separated by thin layer-chromatography. The results were quantified by using a Pacard Liquid Scintillation System (TRI-CARD 2660).

\section{2) Inhibition of lipoxygenase enzyme.}

Drugs were dissolved in a borate buffer $(0.2 \mathrm{M}, \mathrm{pH}: 9.0)$ in a concentration of $10^{-4}$. Linolenic acid (Sigma) served as substrate. Enzymatic reaction was induced by soya-bean lipoxygenase (Sigma).

\section{Table 1.}

Group 1

\begin{tabular}{|c|c|c|c|c|c|c|}
\hline $\begin{array}{c}\text { Age } \\
\text { (years) }\end{array}$ & Sex & Diagnosis & $\begin{array}{c}\text { Latency } \\
\text { of fever } \\
\text { (h) }\end{array}$ & $\begin{array}{r}\text { Effec } \\
\text { dipyrone }\end{array}$ & $\begin{array}{l}\text { sof } \\
\text { ethacin }\end{array}$ & $\begin{array}{c}\text { Infection } \\
\text { verified }\end{array}$ \\
\hline 15 & f & $\begin{array}{l}\text { contusion } \\
\text { cerebri }\end{array}$ & 22 & - & + & - \\
\hline 28 & $\mathrm{~m}$ & $\begin{array}{l}\text { contusion } \\
\text { cerebri }\end{array}$ & 10 & - & + & - \\
\hline 24 & $\mathrm{~m}$ & $\begin{array}{l}\text { haematoma } \\
\text { epidural }\end{array}$ & 7 & - & + & - \\
\hline 37 & m & $\begin{array}{l}\text { haematoma } \\
\text { subdural }\end{array}$ & 14 & - & + & - \\
\hline 9 & $\mathrm{~m}$ & $\begin{array}{l}\text { st. p. op. } \\
\text { tu. cerebelli }\end{array}$ & 5 & - & + & - \\
\hline 17 & & $\begin{array}{l}\text { st. p. op. } \\
\text { tu. cerebelli }\end{array}$ & 7 & - & + & - \\
\hline 7 & $\mathrm{~m}$ & $\begin{array}{l}\text { st. p. op. } \\
\text { tu cerebelli }\end{array}$ & 8 & - & + & - \\
\hline 41 & $\mathrm{~m}$ & $\begin{array}{l}\text { st. p. op. } \\
\text { aneurysm. } \\
\text { comm. ant. }\end{array}$ & 6 & - & + & - \\
\hline 55 & f & $\begin{array}{l}\text { st. p. op. } \\
\text { aneurysm. } \\
\text { comm. ant. }\end{array}$ & 4 & - & + & - \\
\hline 32 & f & $\begin{array}{l}\text { haematoma } \\
\text { introcerebr. }\end{array}$ & 12 & - & + & - \\
\hline 36 & $\mathrm{~m}$ & $\begin{array}{l}\text { haematoma } \\
\text { intracerebr. }\end{array}$ & 16 & - & + & - \\
\hline
\end{tabular}

Mean body temperature was $38.7 \pm 0.20^{\circ} \mathrm{C}$ before and $37.0 \pm 0.13^{\circ} \mathrm{C}$ after the treatment, respectively.

Abbreviations: $f$ - female; $m$ - male; + antipyretic effect; - no antipyretic effect; $+/-$ indefinite effect.

\section{RESULTS}

\section{Clinical studies}

In the patients that developed fever within 48 hours after cranial trauma or brain surgery and were resistant to dipyrone treatment indomethacin was effective as an antipyretic in 10 of 11 cases. The decrease of body temperature was at least $0.7^{\circ} \mathrm{C}$ (range $0.7-2.3^{\circ} \mathrm{C}$, mean $1.7^{\circ} \mathrm{C}$ ). Indomethacin was ineffective in only one patient, who had an intracerebral hematoma. In this case only heat dissipation with physical means relieved the hyperthermia. (Table 1, Figure 1)

In the second group of patients in which fever appeared at least 72 hours after cranial trauma or brain surgery, almost all cases resistant to dipyrone were resistant to indomethacin, too. (Table 2) Only in one case (post-operative cerebellar tumour) with dipyrone resistant fever on the 9th postoperative day in conjunction with meningeal infection was indomethacin effective as antipyretic. In this group of patients the infectious origin of the fever was verified bacteriologically in 11 cases out of 15 . Similar bacteriological routine and criteria were applied for both groups. This proportion is similar to the finding of others, ${ }^{10}$ who were able to obtain a correct bacteriological diagnosis in $74 \%$ of the patients with postoperative fever.

\section{Biochemical studies}

In vitro biochemical studies revealed a sharp contrast between the effect of indomethacin and the pyrazolone derivates on the cyclooxygenase enzyme activity. Indomethacin in $10^{-7} \mathrm{M}$ concentration blocked cyclooxigenase activity very effectively (Table 3), while significantly higher concentrations of pyrazolone derivatives exerted only a slight inhibition $\left(10^{-4} \mathrm{M}\right)$. No effect of either drug has been observed on lipoxygenase actions.

\section{Discussion}

Our results show the effectiveness of indomethacin treatment in cases of neurogenic hyperthermia appearing in the first 24 hours after cranial trauma or brain surgery when dipyrone a pyrazolone derivative, was ineffective. Although the body temperature curves clearly prove the ineffectiveness of the dipyrone, the possibility cannot be totally excluded that the reductions in

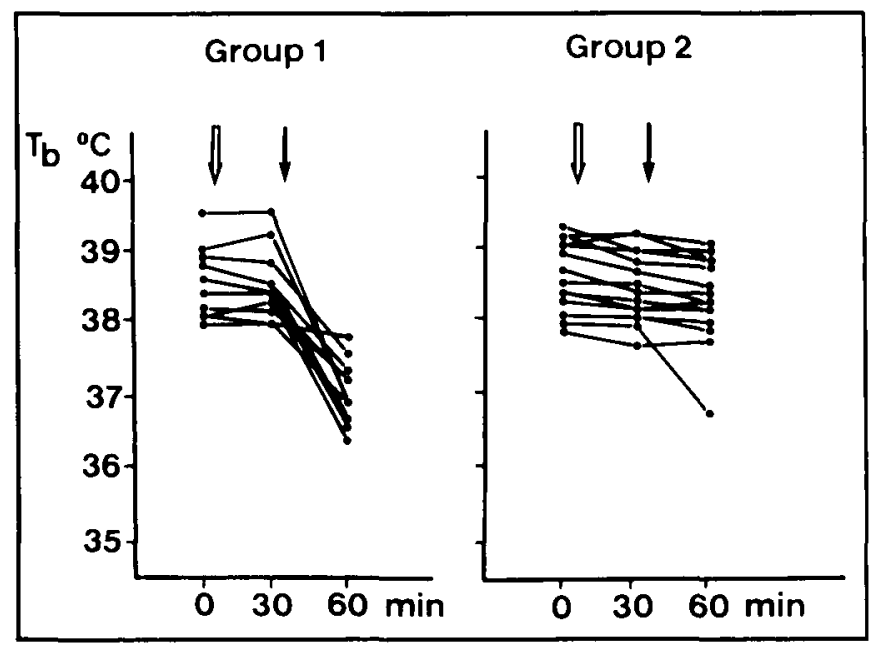

Figure 1 - Body temperature values of patients under the effect of dipyrone $(\|)$ and indomethacin ( | ) treatment. 
temperature observed following indomethacin treatment may in fact be a longer latency effect of the dipyrone.

Our biochemical findings show that pyrazolone derivatives have a poor ability to influence either PG or leukotrien synthesis; hence the differences between indomethacin and dipyrone in clinical testing can be explained on these biochemical terms. Indomethacin, an indole derivative, is one of the most potent

Table 2.

Group 2

\begin{tabular}{|c|c|c|c|c|c|c|}
\hline $\begin{array}{c}\text { Age } \\
\text { (years) }\end{array}$ & & Diagnosis & $\begin{array}{l}\text { Latency } \\
\text { of fever } \\
\text { (h) }\end{array}$ & $\begin{array}{r}\text { Effect } \\
\text { dipyrone }\end{array}$ & $\begin{array}{l}\text { is of } \\
\text { iethacin }\end{array}$ & $\begin{array}{c}\text { Infection } \\
\text { verified }\end{array}$ \\
\hline 58 & $\mathrm{~m}$ & $\begin{array}{l}\text { contusion } \\
\text { cerebri }\end{array}$ & 72 & - & - & pneumonia \\
\hline 48 & $\mathrm{~m}$ & $\begin{array}{l}\text { contusion } \\
\text { cerebri }\end{array}$ & 168 & - & - & $\begin{array}{l}\text { broncho- } \\
\text { pneumonia }\end{array}$ \\
\hline 51 & f & $\begin{array}{l}\text { haematoma } \\
\text { subdural }\end{array}$ & 192 & $+1-$ & - & pneumonia \\
\hline 14 & f & $\begin{array}{l}\text { st. p. op. } \\
\text { tu. cerebelli }\end{array}$ & 168 & - & - & pneumonia \\
\hline 40 & $\mathrm{~m}$ & $\begin{array}{l}\text { st. p. op. } \\
\text { tu. cerebelli }\end{array}$ & 216 & $+1-$ & + & $\begin{array}{l}\text { meningitis } \\
\text { + urinary } \\
\text { infection }\end{array}$ \\
\hline 23 & f & $\begin{array}{l}\text { st. p. op. } \\
\text { tu. cerebelli }\end{array}$ & 96 & - & - & pneumonia \\
\hline 37 & f & st. p. op. & 144 & $+1-$ & - & $\begin{array}{l}\text { urinary } \\
\text { infection }\end{array}$ \\
\hline 50 & f & $\begin{array}{l}\text { st. p. op. } \\
\text { frontocerebr. } \\
\text { meningeoma }\end{array}$ & 216 & - & - & sepsis \\
\hline 45 & f & $\begin{array}{l}\text { meningeoma } \\
\text { basalis }\end{array}$ & 72 & - & - & sepsis \\
\hline 52 & f & $\begin{array}{l}\text { tuberculum } \\
\text { sellae } \\
\text { meningeoma }\end{array}$ & 96 & $+1-$ & - & - \\
\hline 39 & $\mathrm{~m}$ & $\begin{array}{l}\text { st. p. op. } \\
\text { aneurysm. } \\
\text { comm. ant. }\end{array}$ & 168 & - & - & $\begin{array}{l}\text { urinary } \\
\text { infection }\end{array}$ \\
\hline 38 & f & $\begin{array}{l}\text { st. p. op. } \\
\text { aneurysm. } \\
\text { a. car. int. }\end{array}$ & 120 & - & - & pneumonia \\
\hline 45 & $f$ & $\begin{array}{l}\text { st. p. op. } \\
\text { aneurysm. } \\
\text { a. comm. ant. }\end{array}$ & 96 & - & - & - \\
\hline 58 & $\mathrm{~m}$ & $\begin{array}{l}\text { haematoma } \\
\text { intracerebr. }\end{array}$ & 72 & - & - & pneumonia \\
\hline 62 & $\mathrm{f}$ & $\begin{array}{l}\text { haematoma } \\
\text { intracerebr. }\end{array}$ & 96 & $+1-$ & - & - \\
\hline
\end{tabular}

Mean body temperature was $38.6 \pm 0.13^{\circ} \mathrm{C}$ before and $38.3 \pm 0.13^{\circ} \mathrm{C}$ after the treatment, respectively. For abbreviations, see Table 1 .

Table 3: The effect of antipyretics on the activity of cyclooxygenase and lipoxygenase enzymes

\begin{tabular}{|c|c|c|}
\hline \multirow[b]{2}{*}{ Substance } & \multicolumn{2}{|c|}{ INHIBITION OF } \\
\hline & cyclooxygenase activity & lipoxygenase activity \\
\hline $\begin{array}{l}\text { azophen } \\
\text { Antipyrine }\end{array}$ & $5 \%$ inhibition at $10^{-4} \mathrm{M}$ & no inhibition \\
\hline $\begin{array}{l}\text { amidazophen } \\
\text { Aminopyrine }\end{array}$ & $6 \%$ inhibition at $10^{-4} \mathrm{M}$ & no inhibition \\
\hline $\begin{array}{l}\text { novamidazophen } \\
\text { Dipyrine }\end{array}$ & $16 \%$ inhibition at $10^{-4} \mathrm{M}$ & no inhibition \\
\hline Indomethacin & $\mathrm{IC}_{50}=10^{-7} \mathrm{M}$ & no inhibition \\
\hline
\end{tabular}

PG synthetase inhibitors. Despite its potent antipyretic " properties it is still not widely used in treatment of fever. Pyrazolone derivatives, on the other hand, have been proved highly effective antipyretics and analgesics, ${ }^{12}$ although side effects have greatly limited their usage. After some anecdotal reports, ${ }^{13,14}$ Brune and Alperman ${ }^{15}$ reported that pyrazolones in clinical dosage fail to inhibit PG synthesis, and Lorenzetti and Ferreira ${ }^{16}$ proved that dipyrone acts differently from non-steroidal antiinflammatory drugs. No data have appeared yet concerning the effect of pyrazolone derivatives on lipoxygenase activity.

Our results demonstrating that the three most widely used pyrazolone derivatives are almost ineffective in influencing arachidonic acid metabolism in any route support these findings. We can conclude that the antipyretic effect of pyrazolone derivatives also differ from that of the salicylates and other nonsteroidal antiinflammatory drugs, a central site of action has however been suggested for both of these antipyretic drugs. ${ }^{17,18}$

Rudy et $\mathrm{al}^{5}$ were the first to suggest the use of indomethacin in neurogenic hyperthermia, based on their impressive results with indomethacin treatment of rats with central fever after mechanical brain damage. They attributed the central fever to prostaglandin released from the injured tissue and acting on the surviving tissues of the anterior hypothalamus/preoptic region. This suggestion is in line with the evidence that prostaglandins play a crucial ${ }^{19-22}$ but not obligatory ${ }^{23,24}$ role in the initiation of central fever. The effectiveness of pyrazolone derivatives in reducing experimental neurogenic hypothermia has yet to be tested. Still, the differences between the effectiveness of indomethacin in neurogenic hyperthermia and in fever of infectious origin may suggest considerable differences between pathological mechanisms for these two types of fever.

\section{Acknowledgements}

The authors are greatly indebted to Prof. K.E. Cooper for his valuable help in preparing the manuscript. The comments of Q.J. Pittman and M. Szèkely are also gratefully acknowledged.

\section{REFERENCES}

1. Rudy TA, Studies of fever associated with cerebral trauma and intracranial hemorrhage in experimental animals. In: Fever. Lipton JM, Ed. New York, Raven Press, 1980; 165-175.

2. Anderson E, Haymaker W. Disorders of the hypothalamus and pituitary gland. In: Baker AB, Ed. Clinical Neurology, Vol 3. New York: Hoeber-Harper, 1962; 1339-1405.

3. Petersdorf RG. Disturbance of heat regulation. In: Thorn GW, Adams RD, Braunwald E, Isselbacker KJ, Petersdorf RG, Eds. Harison's Principles in Internal Medicine. 8th Ed. New York. McGraw-Hill, 1977: 53-59.

4. Ackerman D, Rudy TA. Thermoregulatory characteristics of neurogenic hyperthermia in the rat. J Physiol (Lond.) 1980: 307: 59-70.

5. Rudy TA, Williams JW, Yaksh TL. Antagonism of indomethacin of neurogenic hyperthermia produced by unilateral puncture of the anterior hypothalamic/preoptic region. J Physiol (Lond.) $1977 ; 721-736$.

6. Bredt AB, Girey JD. Antipyretic effects of indomethacin in liver metastasis of solid tumors. Cancer 1982; 50: 1430-1433.

7. Silberman HR, McGinn TG, Kremer WB. Control of fever in Hodgkin's disease by indomethacin. JAMA 1965; 194: 127-130.

8. Warshaw AL, Carey RW, Robinson DR. Control of fever associated with visceral cancers by indomethacin. Surgery 1981; 89: 414-416.

9. Grossman S, Zokut R. Methods of Biochemical Analysis. 1979; 25: 33. 
10. Freischlag J, Bussuttil RW. The value of postoperative fever evaluation. Surgery $1983 ; 94: 358-363$.

11. Clark WG, Cumby HR. The antipyretic effect of indomethacin. J Physiol (Lond.) 1975; 248: 625-638.

12. Mukerjee S, Sudhasood L. A controlled evaluation of orally administered aspirin, dipyrone and placebo in patients with postoperative pain. Curr Med Res Op 1980; 6: 619-623.

13. Gryglewski R. Discussion remark. In: Robinson HJ, Vane JR, Eds. Prostaglandin Synthetase Inhibitors. New York, Raven Press, $1974 ; 77$.

14. Brune K, Alperman H. Non-acidic pyrazoles: inhibition of prostaglandin production, carrageenin oedema and yeast fever. Agents and Actions 1984: 13: 360-363.

15. Shen TY. Discussion remark. In: Robinson HJ, Vane JR, Eds. Prostaglandin Synthesis Inhibitors, New York, Raven Press $1974 ; 77$.

16. Lorenzetti BB, Ferreira SH. Mode of analgesic action of dipyrone: direct antagonism of inflammatory hyperalgesia. Eur J Pharmacol 1985; 114: 375-381.

17. Clark WG, Aldridge MT. Inhibition of leucocyte pyrogen-induced fever by intraventriculat administration of salicylate and acetaminophen in the cat. Proc Soc Exp Biol Med 1972; 140: 399-403.
18. Davison G, Guy JL, Levitt M, et al. The distribution of certain non-narcotic agents in the CNS of several species. J Pharm Exp Ther 1961; 134: 176-183.

19. Feldberg W, Saxena PN. Further studies on prostaglandin $E_{1}$ fever in cats. J Physiol (Lond.) 1971; 219: 739-745.

20. Pittman QJ, Veale JW, Cooper KE. Temperature responses of lambs after centrally injected prostaglandins and pyrogens. Amer J Physiol 1975; 228: 1034-1038.

21. Stitt JT. Prostaglandin $E_{1}$ fever induced in rabbits. J Physiol (Lond.) $1973 ; 232: 240-245$.

22. Veale WL, Cooper KE, Comparison of sites of action of prostaglandin $\mathrm{E}$ and leucocyte pyrogen in brain. In: Lomax $\mathrm{P}$, Schönbaum E, Jacob J, Eds. Temperature Regulation and Drug Action, New York - Basel, Karger, 1975; 218-226.

23. Cooper KE. The neurobiology of fever - Thoughts on recent developments. In press 1986.

24. Mitchell D, Laburn $\mathrm{H}$, Cooper KE, et al. Is prostaglandin $\mathrm{E}$ the neural mediator of the febrile response? The case against a proven obligatory role. Yale J Biol Med in press. 